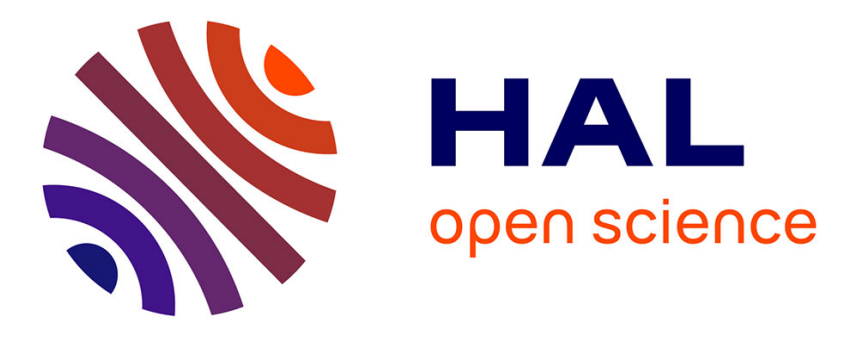

\title{
Electro-Fenton pretreatment for the improvement of tylosin biodegradability
}

Fatiha Ferrag-Siagh, Florence Fourcade, Isabelle Soutrel, Hamid Aït-Amar, Hayet Djelal, Abdeltif Amrane

\section{- To cite this version:}

Fatiha Ferrag-Siagh, Florence Fourcade, Isabelle Soutrel, Hamid Aït-Amar, Hayet Djelal, et al.. Electro-Fenton pretreatment for the improvement of tylosin biodegradability. Environmental Science and Pollution Research, 2014, 21 (14), pp.8534-8542. 10.1007/s11356-014-2771-5 . hal-00980130

\section{HAL Id: hal-00980130 \\ https://hal.science/hal-00980130}

Submitted on 24 Oct 2014

HAL is a multi-disciplinary open access archive for the deposit and dissemination of scientific research documents, whether they are published or not. The documents may come from teaching and research institutions in France or abroad, or from public or private research centers.
L'archive ouverte pluridisciplinaire HAL, est destinée au dépôt et à la diffusion de documents scientifiques de niveau recherche, publiés ou non, émanant des établissements d'enseignement et de recherche français ou étrangers, des laboratoires publics ou privés. 
2

3 Fatiha Ferrag-Siagh ${ }^{1,3,5}$, Florence Fourcade ${ }^{1,2^{*}}$, Isabelle Soutrel ${ }^{1,2}$, Hamid Aït-Amar ${ }^{3}$, Hayet Djelal ${ }^{1,2,4}$,

4 Abdeltif Amrane ${ }^{1,2}$

$5 \quad{ }^{1}$ Université de Rennes 1, Ecole Nationale de chimie de Rennes, CNRS, UMR 6226, 11 allée de Beaulieu, CS $6 \quad 50837,35708$ Rennes Cedex 7, France.

$7 \quad{ }^{2}$ Université Européenne de Bretagne, 5 Boulevard Laënnec, 35000 Rennes, France.

8 [3niversité des Sciences et de la Technologie Houari Boumediene, Laboratoire des Sciences de Génie des 9 Procédés Industriels, USTHB, B.P. 32, 16111, El-Alia, Alger, Algérie.

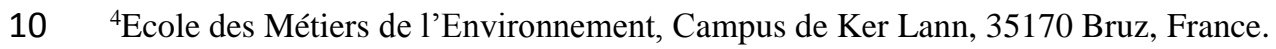

${ }^{5}$ Université Mouloud Mammeri de Tizi-Ouzou, Facultés des Sciences, Département de chimie 15000, Algérie. 


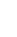

\section{Abstract}

The feasibility of an electro-Fenton process to treat tylosin (TYL), a non-biodegradable antibiotic, was examined in a discontinuous electrochemical cell with divided cathodic and anodic compartments. Only 15 min electrolysis were needed for total tylosin degradation using a carbon felt cathode and a platinium anode; while $6 \mathrm{~h}$ electrolysis were needed to achieve high oxidation and mineralization yields, $96 \%$ and $88 \%$ respectively. Biodegradability improvement was shown since $\mathrm{BOD}_{5} / \mathrm{COD}$ increased from 0 initially to 0.6 after $6 \mathrm{~h}$ electrolysis (for $100 \mathrm{mg} \mathrm{L}^{-1}$ initial TYL). With the aim of combining electro-Fenton with a biological treatment, an oxidation time in the range 2 to $4 \mathrm{~h}$ has been however considered. Results of AOS (Average Oxidation State) and COD/TOC suggested that the pre-treatment could be stopped after $2 \mathrm{~h}$ rather than $4 \mathrm{~h}$; while in the same time, the increase of biodegradability between 2 and $4 \mathrm{~h}$ suggested that this latter duration seemed more appropriate. In order to conclude, biological cultures have been therefore carried out for various electrolysis times. TYL solutions electrolyzed during 2 and $4 \mathrm{~h}$ were then treated with activated sludge during 25 days, showing 57 and $67 \%$ TOC removal respectively, namely 77 and $88 \%$ overall TOC removal if both processes were considered. Activated sludge cultures appeared therefore in agreement with the assessment made from the analysis of physico-chemical parameters (AOS and COD/TOC), since the gain in terms of mineralization expected from increasing electrolysis duration appeared too low to balance the additional energy consumption.

Key words: Tylosin, Electro-Fenton process, Degradation, Mineralization, Biological treatment.

\section{Introduction}

2

The occurrence of a great number of pharmaceutical residues in the environment has been frequently reported in recent literature, receiving increasing attention as emerging contaminants [1-4]. Antibiotics are widely used in human and veterinary medicine to prevent or treat microbial infections, as well as growth factors in livestock production. After administration, fifty to ninety percent of these pharmaceuticals or their primary metabolites are excreted rapidly by humans as well as animals. After excretion, antibiotics are transferred to sewage treatment plants (STPs). Antibiotics may adsorb to the sewage sludge or leave the treatment plant unchanged with the STP discharge water [5].

Among veterinary pharmaceuticals, tylosin is a macrolide antibiotic produced by a strain of Streptomyces fradiae. It displays good anti-bacterial activity against most pathogenic gram-positive bacteria, and some gram- 
negative bacteria, Vibrio, spirochete, coccidian, etc. It is one of the first-choice drugs against infections caused by mycoplasma [6]. The chemical structure of tylosin is given in Fig.1.

Tylosin is widely used for therapeutics and growth promotion in swine, beef cattle, and poultry production [7], while only a part of the administered antibiotic is metabolized; the part left is found back in its active form in animal's excreta, which is therefore found in wastewaters produced from livestock production. The absence of biodegradability of tylosin was previously demonstrated using a modified Sturm-test (OECD 301 B) [8]. The inhibitory effect of tylosin on anaerobic treatment in sequencing batch reactor have been studied by Shimada et al. [9]. The addition of tylosin (167 ppm) has induced a gradual decrease of methane production and the accumulation of metabolites such as propionate and acetate in the culture medium along with a $\mathrm{pH}$ decrease. As a consequence, tylosin addition has negatively impacted the overall system. In batch tests, the specific biogas production was also completely inhibited in the presence of tylosin. According to these authors [10], this failure was the consequence of the direct inhibition of propionate-oxidizing syntrophic bacteria, closely related to Syntrophobacter and the indirect inhibition of Methanosaeta by high propionate concentration and low $\mathrm{pH}$. This inhibition was also noticed by Stasinakis [11].

The biologic deactivation of tylosin has been carried out by ozonation at a concentration of $1 \mathrm{mM} \mathrm{[12];} \mathrm{this}$ physico-chemical process has been studied for an application on municipal wastewater treatment.

Advanced oxidation processes (AOP) are considered good alternatives due to their high efficiency in oxidizing a great variety of organic compounds by the generation of highly oxidizing hydroxyl radicals [13-17]. Considering tylosin degradation, interesting results have been obtained with a photocatalytic treatment under UV irradiation using $\mathrm{TiO}_{2}$ in suspension [18] or fixed on a non-woven paper [19]; 97\% of tylosin was degraded in less than 60 min using $0.05 \mathrm{~g} \mathrm{~L}^{-1}$ of $\mathrm{TiO}_{2}$ suspension. When $\mathrm{TiO}_{2}$ was fixed $\left(25 \mathrm{~g} \mathrm{~m}^{-2}\right), 2 \mathrm{~h}$ were needed to degrade $90.4 \%$ of the compound.

Even though AOPs have been shown to be highly efficient, their operation is still quite expensive. An attractive option is a short AOP pretreatment which let expect the formation of biodegradable intermediates of the recalcitrant pollutants, which can be subsequently degraded in a biological process, with the aim of reducing energy costs. For example, in a previous study, after tylosin degradation by photocatalysis, 56\% COD decrease was reached by means of a biological culture [19]. Therefore, before examination of the combination of an AOP with a conventional biological treatment for pollutant removal, the relevance of an AOP pre-treatment has to be checked by the monitoring of some specific parameters such as the target compound concentration or that of global parameters like total organic carbon (TOC), chemical oxygen demand (COD), biodegradability of the 
pretreated pollutant solution through biological oxygen demand $\left(\mathrm{BOD}_{5}\right)$ measurements. The evolution of global parameters like TOC, COD, COD/TOC and AOS also provide useful information on mineralization and oxidation; while the $\mathrm{BOD}_{5}$ on $\mathrm{COD}$ ratio approximates effluent biodegradability, since a value of 0.4 is considered by several authors as the boundary of biodegradability [20-22].

Heterogeneous photocatalysis is interesting in water purification because $\mathrm{TiO}_{2}$, the most used catalyst, is not expensive and no more chemical reagents are needed to degrade organic pollutants at neutral $\mathrm{pH}$ [19]. Another AOP, electro-Fenton, an indirect electrochemical advanced oxidation process derived from Fenton reaction, is also a promising technology for the treatment of wastewaters [23,24]. Indeed, it does not involve the use of harmful chemical reagents due to the fact that the reactants are in situ electro-generated; moreover the method is easy to handle and the reactors involved are simple.

$\mathrm{H}_{2} \mathrm{O}_{2}$ is continuously generated by reduction of the dissolved molecular $\mathrm{O}_{2}$ in mildly acidic aqueous medium (Eq. (1)) using various cathodes materials [23].

$$
\mathrm{O}_{2}+2 \mathrm{H}^{+}+2 \mathrm{e}-\rightarrow \mathrm{H}_{2} \mathrm{O}_{2} \quad E^{\circ}=0.69 \mathrm{~V} / \mathrm{SHE}
$$

Hydroxyl radical $\left(\mathrm{OH}^{\bullet}\right)$ and $\mathrm{Fe}^{3+}$ ions are then generated from the classical Fenton's reaction between $\mathrm{Fe}^{2+}$ ions and $\mathrm{H}_{2} \mathrm{O}_{2}$

$$
\mathrm{Fe}^{2+}+\mathrm{H}_{2} \mathrm{O}_{2} \rightarrow \mathrm{Fe}^{3+}+\cdot \mathrm{OH}+\mathrm{OH}^{-} \text {(Fenton's reaction) }
$$

$\mathrm{Fe}^{2+}$ ions in catalytic amount were consumed by Fenton's reaction in the homogeneous medium (Eq. (2)) and are regenerated at the cathode by reduction of $\mathrm{Fe}^{3+}$ ions (Eq. (3))

$$
\mathrm{Fe}^{3+}+1 \mathrm{e}-\quad \rightarrow \mathrm{Fe}^{2+} \quad E^{\circ}=0.77 \text { V/SHE }
$$

Electro-Fenton was developed and widely applied for oxidation of various organic pollutants [24-29]. Recently, integrated processes such as electro-Fenton / electro-oxidation allowed a higher production of hydroxyl radicals and then a higher mineralization of the effluent [30,31]. Among the studied materials, boron-doped diamond [30], $\mathrm{Ce} / \mathrm{SnO}_{2}-\mathrm{Sb}$ coated titanium [31] can be used as efficient anode materials. Air-diffusion cathodes were implemented for a better oxygen supply at the electrode surface and then a higher production of hydrogen peroxide [30]. Another way to increase the hydroxyl radicals production is to integrate UVA radiations in the photoelectro-Fenton process as in the photoelectron-Fenton process [32].

The aim of this study was therefore to examine the relevance of the electro-Fenton process for the removal of tylosin and its possible combination with a biological treatment. Previous studies showed biodegradability enhancement of solutions after electro-Fenton oxidation of antibiotics $[27,33]$. The combination between electroFenton and a biological treatment has been already tested on landfill leachate [34], olive oil mill wastewater [35], 
formaldehyde [36] but not on such toxic effluent as those containing antibiotics except a previous study on tetracycline from our lab [29]. In order to select the most appropriate pretreatment duration, the first step was to study the performance of an electro-Fenton pre-treatment through the monitoring of antibiotic degradation, its oxidation and mineralization, and especially the monitoring of global parameters, like COD/TOC, AOS and biological oxygen demand.

In order to validate the biodegradability results assessed from the $\mathrm{BOD}_{5} / \mathrm{COD}$ ratio, subsequent biological cultures were then considered.

\section{Material and methods}

\subsection{Chemicals and reagents}

Tylosin tartrate (Fluka 5 g packaging, purity > $95 \%$ ) was obtained from Sigma-Aldrich (St Quentin Fallavier, France). Solution $\mathrm{pH}$ was adjusted by adding sulphuric acid $\left(\mathrm{H}_{2} \mathrm{SO}_{4} ; 96 \%\right.$ purity) or sodium hydroxide $(\mathrm{NaOH})$ solutions obtained from Sigma Aldrich and Fisher, respectively. Methanol (MeOH) was UPLC grade from Fisher Scientific (Illkirch, France); Formic acid was Fisher Scientific. Catalyst heptahydrated ferrous sulfate $\left(\mathrm{FeSO}_{4}, 7 \mathrm{H}_{2} \mathrm{O}\right)$ and anhydrous sodium sulfate $\left(\mathrm{Na}_{2} \mathrm{SO}_{4}\right)$ were supplied by Acros Organics (Geel, Belgique). Ultra pure water (Purelab Options-Q7/15, Elga, 18.2M $\Omega \mathrm{cm}$ ) was used in all experiments. All the reagents and materials used in this study were of analytical grade.

\subsection{Electro-Fenton oxidation experiments}

Tylosin oxidation was performed at room temperature in cylindrical glass cell of $1 \mathrm{~L}$ ( $10 \mathrm{~cm}$ inner diameter), equipped with a carbon-felt cathode whose surface was $194 \mathrm{~cm}^{2}$ piece (Carbone Lorrain, RVG 4000-Mersen, Paris La Defense, France) $(13 \times 6 \mathrm{~cm})$ of $1 \mathrm{~cm}$ thickness. It was placed on the inner wall of the cell. Its specific area, measured by the BET method, was $0.7 \mathrm{~m}^{2} \mathrm{~g}^{-1}$ and its density was $0.088 \mathrm{~g} \mathrm{~cm}^{-3}$. A cylindrical glass of 150 $\mathrm{mL}(5 \mathrm{~cm}$ diameter) was placed in the center of the cell, equipped with a cylindrical platinum anode $(5 \mathrm{~cm} \times 1$ $\mathrm{cm}$ ) and the electrolytic solution of $0.05 \mathrm{M}_{\text {of }} \mathrm{Na}_{2} \mathrm{SO}_{4}$ at $\mathrm{pH}=3$. The two electrodes were connected to a DC Amperemeter power supply (Microsonic systems, Microlab MX 300V-1A, France). Continuous saturation of the solution by $\mathrm{O}_{2}$ at atmospheric pressure was ensured by bubbling compressed air, which was beforehand acidified by passage through a solution of $0.5 \mathrm{M} \mathrm{H}_{2} \mathrm{SO}_{4}$, at a flow rate of $4.5 \mathrm{~L} \mathrm{~min}^{-1}$, and starting $30 \mathrm{~min}$ before electrolysis to reach a stationary $\mathrm{O}_{2}$ concentration. The TYL concentration was $100 \mathrm{mg} \mathrm{L}^{-1}, 0.1 \mathrm{mM} \mathrm{Fe}^{2+}$ catalyst 
151

152

153

154

155

156

157

158

159

160

161

162

163

164

165

166

167

168

concentration was added and the current intensity was maintained constant at $300 \mathrm{~mA}$. Experiments were performed at pH 3.0 (Hanna Instruments pH-meter 211, Lingolshieim, France, Alsace), namely close to the optimal $\mathrm{pH}$ of 2.8 reported for the Fenton's reaction Eq. (2) [28,37]; it was maintained constant throughout experiments by $2 \mathrm{M} \mathrm{H}_{2} \mathrm{SO}_{4}$ addition. The working volume was $600 \mathrm{~mL}$ and the agitation rate was $1500 \mathrm{rpm}$, to ensure an efficient mass transfer towards/from the electrodes. These experimental conditions are taken from a previous study on the removal of tetracycline and gave the optimal results regarding molecule degradation and its mineralization [29].

\subsection{Analysis}

Samples were filtered through $0.45 \mu \mathrm{m}$ membrane filter and tested for chemical oxygen demand (COD), biological oxygen demand $\left(\mathrm{BOD}_{5}\right)$, total organic carbon (TOC) and filtered through $0.2 \mu \mathrm{m}$ membrane filter for measurement of antibiotics residual concentration by UPLC.

\subsubsection{Ultra Performance Liquid Chromatography (UPLC)}

The residual tylosin concentration during treatment was monitored by Waters Acquity UPLC ${ }^{\circledR}$ H-Class (Ultra Performance Liquid Chromatography). A $\mathrm{C}_{18} \mathrm{BEH}$ column (Bridged Ethylene Hybrid), $1.7 \mu \mathrm{m}(2.1 \times 50 \mathrm{~mm})$ operated at $45^{\circ} \mathrm{C}$. The separation was performed according to the following gradient elution with methanol (eluant A) and formic acid $0.1 \%$ in ultra-pure water, milli Q-water (eluant B): 10/90\% from 0 to 1 min, from 1 to 4.5 min elution was linearly modified from $10 / 90 \%$ to $98 / 2 \%$, maintained at $98 / 2 \%$ from 4.5 to 5 min, from 5 to 5.5 min elution was linearly modified from $98 / 2 \%$ to $10 / 90 \%$ where it was maintained from 5.5 to 10 min for solvents A and B, respectively.

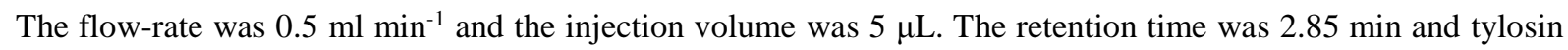
detection was made at a wavelength of $285 \mathrm{~nm}$ with a PDA detector (photodiodes array) allowing an analysis between 210 and $400 \mathrm{~nm}$.

\subsubsection{Chemical Oxygen Demand (COD)}

Chemical oxygen demand (COD) was measured by means of Nanocolor-CSB 40 and 160 tests from Macherey-

Nagel (Düren, Germany). COD concentration was measured by NANOCOLOR ${ }^{\circledR}$ photometer.

\subsubsection{Total Organic Carbon (TOC)}


Total organic carbon (TOC) was measured via a TOC-meter SHIMADZU TOC-VCPH analyzer (Kyoto, Japan). Total organic carbon (TOC) present in the samples was calculated by the subtraction of the inorganic carbon (IC) value from the total carbon (TC) value. Analyses were duplicated.

\subsubsection{Biological Oxygen Demand (BOD5)}

$\mathrm{BOD}_{5}$ measurements were carried out in OxiTop IS12 WTW (Alès, France). Activated sludge was obtained from a municipal wastewater treatment plant (Beaurade, Rennes,France) and was used to inoculate the flasks. Before used for inoculation, sludge was washed three times with drinking water and two times with distilled water to avoid any nutrients other than those contained in the culture media; after each washing, sludge was centrifuged at $3000 \mathrm{rpm}$ for $10 \mathrm{~min}$ (Jouan, Thermo Fisher Scientifics, Saint Herblain, France). A given amount of sludge was resuspended in distilled water, in order to achieve an initial microbial concentration of $0.05 \mathrm{~g} \mathrm{~L}^{-1}$. The following mineral basis was used for all experiments $\left(\mathrm{g} \mathrm{L}^{-1}\right)$ : $\mathrm{MgSO}_{4} \cdot 7 \mathrm{H}_{2} \mathrm{O}, 22.5 ; \mathrm{CaCl}_{2}, 27.5 ; \mathrm{FeCl}_{3}, 0.15$; $\mathrm{NH}_{4} \mathrm{Cl}, 2.0 ; \mathrm{Na}_{2} \mathrm{HPO}_{4}, 6.80 ; \mathrm{KH}_{2} \mathrm{PO}_{4}, 2.80$. The $\mathrm{BOD}_{5}$ value was initially estimated based on the COD value experimentally measured according to the following ratio, $\mathrm{BOD}_{5}=\mathrm{COD} / 1.46$. The volumes of sample, of activated sludge solution and nitrification inhibitor $\left(10 \mathrm{mg} \mathrm{L}^{-1}\right.$ solution of $\mathrm{N}$-allylthiourea) which have to be added in the shake flask were then deduced from the expected range of $\mathrm{BOD}_{5}$ values. Similar protocol was applied for the control sample except that it was replaced by a solution of easily biodegradable compounds, namely glutamic acid $\left(150 \mathrm{mg} \mathrm{L}^{-1}\right)$ and glucose $\left(150 \mathrm{mg} \mathrm{L}^{-1}\right)$. Before use, $\mathrm{NaOH}$ was added to achieve neutral $\mathrm{pH}(7.0 \pm 0.2)$. Similar protocol was also considered for the blank solution, for which the sample was replaced by water to deduce the biological oxygen demand corresponding to the endogenous respiration (negligible $\mathrm{BOD}_{5}$ value) [29]. All sample flaks were duplicated.

\subsection{Biological treatment}

Biological treatments were carried out in aerobic conditions using activated sludge purchased from a local wastewater treatment plant (Station de Beaurade, Rennes, France). Before use, activated sludge was washed three times with tap water and twice with distilled water. After each washing, activated sludge was centrifuged at 3000 rpm for five minutes (Jouan, Thermo Fisher Scientifics, Saint Herblain, France). The supernatant was then separated from the sludge to remove any residual carbon or mineral source.

Cultures were carried out in duplicate experiments for 25 days at $25^{\circ} \mathrm{C}$ in $500 \mathrm{ml}$ Erlenmeyer flasks, which were magnetically stirred (300 rpm), closed with a cellulose cap to ensure oxygenation and loaded with $400 \mathrm{~mL}$ of 
non-treated tylosin $\left(100 \mathrm{mg} \mathrm{L}^{-1}\right)$ or treated tylosin solutions (100 $\mathrm{mg} \mathrm{L}^{-1}$ initial concentration), namely electrolyzed during $2 \mathrm{~h}$ and $4 \mathrm{~h}$. The following mineral supplementation was added in the flasks $\left(\mathrm{mg} \mathrm{L}^{-1}\right)$ : $\mathrm{KH}_{2} \mathrm{PO}_{4}, 43.8 ; \mathrm{Na}_{2} \mathrm{HPO}_{4}, 33.4 ; \mathrm{NHNO}_{3}, 3 ; \mathrm{CaCl}_{2}, 27.5 ; \mathrm{MgSO}_{4}, 7 \mathrm{H}_{2} \mathrm{O}, 22.5$; and trace mineral solution (mg L1): $\mathrm{FeSO}_{4}, 7 \mathrm{H}_{2} \mathrm{O}, 1.36 ; \mathrm{CuSO}_{4}, 2 \mathrm{H}_{2} \mathrm{O}, 0.24 ; \mathrm{ZnSO}_{4}, 5 \mathrm{H}_{2} \mathrm{O}, 0.25 ; \mathrm{NiSO}_{4}, 6 \mathrm{H}_{2} \mathrm{O}, 0.11 ; \mathrm{MnSO}_{4}, \mathrm{H}_{2} \mathrm{O}, 1.01$.

Before use, $\mathrm{NaOH}$ was added to achieve a neutral $\mathrm{pH}(7.0 \pm 0.2)$ and the flasks were inoculated with $0.5 \mathrm{~g} \mathrm{~L}^{-1}$ of activated sludge.

\section{Results and discussion}

\subsection{Degradation and mineralization kinetics of tylosin}

The concentration of TYL decreased exponentially (Fig.2) and the concentration-time curve followed a pseudofirst order kinetic (inset in Fig.2), which allowed deducing the apparent rate constant for TYL degradation (slope of the straight line) according to Eq. (4):

$$
-\frac{d[T Y L)]}{d t}=k_{a b s}[\cdot \mathrm{OH}][T Y L]=k_{a p p}[T Y L]
$$

Where $\mathrm{k}_{\mathrm{abs}}$ is the absolute rate constant of the oxidation of TYL by ${ }^{\bullet} \mathrm{OH}$ and $\mathrm{k}_{\text {app }}$ is the apparent rate constant of this reaction.

Complete degradation of TYL was achieved in $15 \mathrm{~min}$ at $300 \mathrm{~mA}$, with a ferrous concentration of $0.1 \mathrm{mM}$, sodium sulfate concentration of $0.05 \mathrm{M}$ and $\mathrm{pH} 3$. This high and rapid degradation could be attributed to the break of ether functions in the molecule [19]. Mineralization of aqueous TYL solutions during treatment was monitored through the TOC evolution (Fig.3). TOC values decreased exponentially with time, until reaching significant mineralization yields, 45, 62 and $88 \%$ after 2, 4 and $6 \mathrm{~h}$ electrolysis respectively (table 1 ). The same trend has been observed during the electro-Fenton treatment of sulfachloropyridazine with a carbon felt cathode and a platinum anode [25]. Indeed, $59.2 \mathrm{ppm}(0.2 \mathrm{mM})$ of sulfachloropyridazine has been degraded after about 10 min of oxidation with a current intensity of $300 \mathrm{~mA}$ and a mineralization yield of $79 \%$ has been obtained after 4h.

The aim of the electro-Fenton step was to increase its biodisponibility leading to more readily biodegradable byproducts of the target compound. This can be expected, owing to the total tylosin degradation, while partial 
mineralization was observed indicating a significant remaining amount of residual carbon available for a subsequent biological treatment.

\subsection{COD analysis and estimation of the pre-treatment duration}

A decrease of the chemical oxygen demand generally involves a chemical oxidation of the target compound and hence a modification of its chemical structure which could lead to an increase of its biodegradability. On the other hand, a limited mineralization is required to ensure sufficient residual organic carbon for subsequent biologic treatment. As a consequent a favorable trend is a decrease of the ratio COD/TOC [20,21].

For increasing electrolysis time, the COD values decreased from $136 \mathrm{mg} \mathrm{O}_{2} \mathrm{~L}^{-1}$ for the non-treated target compound to 46, 30 and $5 \mathrm{mg} \mathrm{O}_{2} \mathrm{~L}^{-1}$ after 2, 4 and 6 h oxidation times, respectively (Table 1). The evolution of the COD on TOC ratio was favorable, since the COD/COT decreased. This ratio decreased up to $2 \mathrm{~h}$ of electrolysis; it remained then constant from 2 to $4 \mathrm{~h}$ and finally decreased up to $6 \mathrm{~h}$ of electrolysis. It can be supposed that between 2 and $4 \mathrm{~h}$, the chemical structure of compounds in solution did not vary significantly [38]. In the same way, the Average Oxidation State (AOS) [21], has been calculated according to equation 5:

$$
A O S=\frac{4(T O C-C O D)}{T O C}
$$

Where TOC and COD are expressed in moles of $\mathrm{C}$ per liter and moles of $\mathrm{O}_{2}$ per liter, respectively. The maximum value +4 corresponds to the most oxidized state of carbon, $\mathrm{CO}_{2}$, and the minimum value -4 corresponds to the most reduced state of carbon, $\mathrm{CH}_{4}$.

When the AOS remains constant, Parra et al. [39] suggest that the chemical nature of the intermediates does no vary anymore. In these conditions, the AOS of the treated solution could be an indirect indication of the ability of the pre-treatment to improve the biodegradability of the solution.

From these results, it seems more judicious to stop the pre-treatment after $2 \mathrm{~h}$ rather than after $4 \mathrm{~h}$ of electrolysis. Concerning a more extended electrolysis, electro-Fenton could be considered alone, since $96 \%$ of oxidation and $88 \%$ of mineralization were obtained after $6 \mathrm{~h}$ of treatment.

\subsection{Biodegradability of the electrolyzed solution}

The biodegradability test was performed with a solution electrolyzed under the following conditions: $100 \mathrm{mg} \mathrm{L}^{-1}$

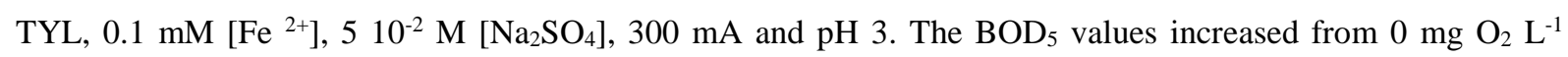
initially (non-treated tylosin) to $14-15 \mathrm{mg} \mathrm{O}_{2} \mathrm{~L}^{-1}$ after 2 and $4 \mathrm{~h}$ oxidation time and then decreased to $3 \mathrm{mg} \mathrm{O}_{2}$ 
$\mathrm{L}^{-1}$ after $6 \mathrm{~h}$ oxidation time, leading to $\mathrm{BOD}_{5} / \mathrm{COD}$ ratios increasing from 0 initially to $0.3,0.5$ and 0.6 for 2,4 and $6 \mathrm{~h}$ electrolysis, respectively (Table 1). These results showed the biodegradability of the electrolyzed effluent, since a value of 0.4 was reached, confirming the relevance of the electro-Fenton pre-treatment. It should however be noted that in the case of a long pre-treatment time $(6 \mathrm{~h})$, the high $\mathrm{BOD}_{5}$ on $\mathrm{COD}$ ratio (Table 1) should be balanced by the high mineralization yield also obtained (88\% - Fig.3), indicating a low residual amount of organic content $\left(6.8 \mathrm{mg} \mathrm{L}^{-1}-\right.$ Table 1) available for the subsequent biological treatment. The optimal oxidation time should be therefore most likely between 2 and $4 \mathrm{~h}$, since after 2 and $4 \mathrm{~h}$ electrolysis the treated solution was almost biodegradable $\left(\mathrm{BOD}_{5} / \mathrm{COD}=0.3\right)$ and biodegradable $\left(\mathrm{BOD}_{5} / \mathrm{COD}=0.5\right)$ for moderate mineralization yields, 45 and 62\% (Fig.3), respectively. Previous results of AOS and COD/TOC (Table 1) seemed to suggest that the pre-treatment could be stopped after $2 \mathrm{~h}$ rather than $4 \mathrm{~h}$; however, this latter electrolysis time seemed more appropriate since biodegradability increased between 2 and $4 \mathrm{~h}$. In order to conclude, biological treatments have been therefore carried out for various electrolysis times.

\subsection{Biological treatment}

The negligible TYL biosorption on the sludge can be noted in Fig. 4 and the recalcitrance of tylosin $\left(100 \mathrm{mg} \mathrm{L}^{-1}\right)$ was confirmed at the examination of Fig.5, since the ratios of the total organic carbon on its initial value $\left(\mathrm{TOC}_{\mathrm{t}} / \mathrm{TOC}_{0}\right)$ remained constant even after 25 days of culture. It was also in agreement with previous findings [8], showing a maximum tylosin adsorption capacity of $7.7 \mathrm{mg}$ per g of activated sludge, namely less than $4 \mathrm{mg}$ $\mathrm{L}^{-1}$ at best for $0.5 \mathrm{~g} \mathrm{~L}^{-1}$ activated sludge as considered in this work, leading to less than $4 \%$ tylosin biosorption (100 $\mathrm{mg} \mathrm{L}^{-1}$ initial concentration).

Contrarily, the electrolyzed TYL solutions appeared partially biodegradable by activated sludge (Fig.5). Indeed, after only two days of culture, TOC decrease were about 46 and $56 \%$ for solutions pretreated during 2 and $4 \mathrm{~h}$ (Fig.5), leading to 31 and $40 \%$ biodegradation if the adsorbed amounts were taken into account (Fig.4), respectively. A significant part of the by-products resulting from electrolysis were therefore readily biodegradable. It can be noticed that at equilibrium, reached in less than $3 \mathrm{~h}$, the part of adsorbed by-products were close to 15 and $16 \%$ for 2 and $4 \mathrm{~h}$ electrolysis pre-treatment (Fig.4). Biodegradation continued at lower rates throughout cultures, and after 25 days of activated sludge culture, final TOC decrease were close to 57 and $67 \%$ for 2 and $4 \mathrm{~h}$ pretreatment, respectively (Fig.5), namely 42 and $51 \%$ biodegradation after subtraction of the adsorption part. 
It can be noticed that the mineralization of by products was similar to that obtained after photocatalysis [19] for similar pre-treatment durations.

301

302

303

304

305

306

307

308

309

310

311

312

313

314

315

316

317

318

319

320

321

322

323

324

325

326

327

If the pretreatment was also taken into account, the overall TOC decrease were therefore 77 and $88 \%$ after 25 days activated sludge culture of TYL solutions electrolyzed 2 and $4 \mathrm{~h}$ respectively. They corresponded to the sum of 45 and $62 \%$ TOC removal during electrolysis and 32 and $26 \%$ TOC removal during biological treatment related to the initial TOC amounts, respectively.

From this, only $10 \%$ increase was obtained for two supplementary hours of electrolysis. Therefore the gain in terms of mineralization did not balance the additional energy costs. It can be also noticed that the increase of biodegradability between 2 and $4 \mathrm{~h}$ seems to be related to the increase of mineralization during this time (decrease of TOC values from 32.2 to $22.0 \mathrm{mg} \cdot \mathrm{L}^{-1}$ ), $\mathrm{BOD}_{5}$ values remaining constant. From this, the oxidative pretreatment induced a modification of the chemical nature of the organic compounds, leading to an improvement of the biodegradability. However, the physico-chemical mineralization of part of these by products did not favor significantly the activated sludge culture.

\section{Conclusion}

The efficiency of the electro-Fenton process for the removal of tylosin antibiotic was shown. Under the considered operating conditions, namely $100 \mathrm{mg} \mathrm{L}^{-1}$ tylosine, an applied current of $300 \mathrm{~mA}$, an $\mathrm{Fe}^{2+}$ catalyst concentration of $0.1 \mathrm{mM}$ and an electrolyte $\mathrm{Na}_{2} \mathrm{SO}_{4}$ concentration of $0.05 \mathrm{M}$, at $\mathrm{pH} 3$, total tylosin degradation was achieved after 15 minutes and followed a pseudo first-order reaction; while mineralization yields were 45, 62 and $88 \%$ after 2, 4 and $6 \mathrm{~h}$ electrolysis respectively.

A decrease of the COD/TOC ratio and an increase of the AOS were experimentally observed during the pretreatment step showing favorable trend for biodegradability improvement, as confirmed by the increase of the $\mathrm{BOD}_{5} / \mathrm{COD}$ ratio, from 0 initially to 0.6 after $6 \mathrm{~h}$ electrolysis (for $100 \mathrm{mg} \mathrm{L}^{-1}$ initial TYL concentration), namely above the limit of biodegradability (0.4).

In view of these results, two possibilies can be envisaged. Electro-Fenton process can be carried out upstream of an existing biological step. The preconized electrolysis duration was then estimated at $2 \mathrm{~h}$ with regards to the evolution of the ratios COT/TOC and AOS, even if after $2 \mathrm{~h}$ the ratio $\mathrm{BDO}_{5} / \mathrm{COD}$ continued to increase. Indeed, considering mineralization improvement during the biological treatment, the gain obtained was too low to balance the additional energy consumed. 
328 In view of comparison, the implementation of electro-Fenton as sole mineralization process should also be 329 examined. The physico-chemical treatment of tylosin during $6 \mathrm{~h}$ led to $96 \%$ and $88 \%$ oxidation and 330 mineralization, respectively. Indeed, from an energetic standpoint and at this step of the study, a sole electro331 Fenton treatment seems more appropriate than the combination of $2 \mathrm{~h}$ electro-Fenton pre-treatment followed by a 332 biological treatment. However, none of these processes has been optimized in order to reduce duration especially regarding the biological treatment. Therefore, the choice of the most relevant method for tylosin depollution

334 appeared therefore premature and irrelevant at this stage. For this purpose and after its optimization, further works should be conducted dealing with the energy cost of such combined process. 


\section{References}

[1] Kümmerer, K., Antibiotics in the aquatic environment- A review- Part II. Chemosphere 2009, 75, 435-441.

[2] Clarke, B. O.; Smith, S. R., Review of "emerging" organic contaminants in biosolids and assessment of international research priorities for the agricultural use in biosolids. Environ. Int. 2011, 37, 226-247.

[3] Schricks, M. B.; Heringa, M. B.; Van Der Kooi, M. M. E.; De Voogt, P.; Van Wezel, A. P., Toxicological relevance of emerging contaminants for drinking water quality. Water Res. 2010, 44, 461-476.

[4] Matamoros, V.; Arias, C. A.; Nguyen, L. X.; Salvado, V.; Brix, H., Occurrence and behavior of emerging contaminants in surface water and a restored wetland. Chemosphere 2012, 88, 1083-1089.

[5] Schlüsener, M. P.; Bester, K., Persistence of antibiotics such as macrolides, tiamulin and salinomycin in soil. Environ. Poll. 2006, 143, 565-571.

[6] Chelliapan, S.; Wilby, T.; Sallis, P., Treatment of pharmaceutical wastewater containing tylosin in an anaerobic-aerobic reactor system. Water Pract. Tech. 2010, 5, doi:10.2166/WPT.2010.016.

[7] Hu, D.; Coats, J. R., Aerobic degradation and photolysis of tylosin in water and soil. Environ. Toxicol. Chem. 2007, 26, 884-889.

[8] Prado, N.; Ochoa, J.; Amrane, A., Biodegradation and biosorption of tetracycline and tylosin antibiotics in activated sludge system. Process Biochem. 2009, 44, 1302-1306.

[9] Shimada, T.; Zilles, J. L.; Morgenroth, E.; Raskin, L., Inhibitory effects of the macrolide antimicrobial tylosin on anaerobic treatment. Biotech. Bioeng. 2008, 101, 73-82.

[10] Shimada, T.; Li, X.; Zilles, J. L.; Morgenroth, E.; Raskin, L., Effects of antimicrobial tylosin on the microbial community structure of an anaerobic sequencing batch reactor. Biotech. Bioeng. 2011, 108, 296-305.

[11] Stasinakis, A. S., Review on the fate of emerging contaminants during sludge anaerobic digestion. Bioresource Technol. 2012, 121, 432-440.

[12] Dodd, M. C.; Kolher, H. P. E.; Von Guten, U., Oxidation of antibacterial compounds by ozone and hydroxyl radical: elimination of biological activity during aqueous ozonation processes. Environ. Sci. Technol. 2009, 43, 2498-2504.

[13] Klavarioti, M.; Mantzavinos, D.; Kassinov, D., Removal of residual pharmaceuticals from aqueous systems by advanced oxidation processes. Environ. Int. 2009, 35, 402-417.

[14] Cañizares, P.; Paz, R.; Sàez, C.; Rodrigo, M. A., Electrochemical oxidation of wastewaters polluted with aromatics and heterocyclic compounds. J. Electrochem. Soc. 2007, 154, E165-E171.

[15] Borràs, N.; Arias, C.; Oliver, R.; Brillas, E., Mineralization of desmetryne by electrochemical advanced oxidation processes using a boron-doped diamond anode and an oxygen-diffusion cathode. Chemosphere 2011, $85,1167-1175$.

[16] Yahiaoui, I.; Aissani-Benissad, F.; Fourcade, F.; Amrane, A., Response surface methodology for the optimization of the electrochemical degradation of phenol on $\mathrm{Pb} / \mathrm{PbO}_{2}$ electrode. Environ. Prog. 2012, 31, 515523.

[17] Oller, I.; Malato, S.; Sánchez-Pérez, J. A., Combination of Advanced Oxidation Processes and biological treatments for wastewater decontamination-A review. Sci. Total Environ. 2011, 409, 4141-4166.

[18] Tassalit, D.; Laoufi, A. N.; Bentahar, F., Photocatalytic deterioration of tylosin in an aqueous suspension using $\mathrm{UV} / \mathrm{TiO}_{2}$. Sci. Adv. Mater. 2011, 3, 944-948. 
[19] Yahiat, S.; Fourcade, F.; Brosillon, S.; Amrane, A., Removal of antibiotics by integrated process coupling photocatalysis and biological treatment - Case of tetracycline and tylosin. Int. Biodeter. Biodegr. 2011, 65, 9971003.

[20] Pulgarin, C.; Invernizzi, M.; Parra, S.; Sarria, V.; Polania, R.; Péringer, P., Strategy for the coupling of photochemical and biological flow reactors useful in mineralization of biorecalcitrant pollutants. Catal. Today 1999, 54, 341-352.

[21] Sarria, V.; Parra, S.; Adler, N.; Péringer, P.; Benitez, N.; Pulgarin, C., Recent developments in the coupling of photoassisted and aerobic biological processes for the treatment of biorecalcitrant compounds. Catal. Today 2002, 76, 301-315.

[22] Fourcade, F.; Yahiat, S.; Elandaloussi, K.; Brosillon, S.; Amrane, A., Relevance of photocatalysis prior to biological treatment of organic compounds. Chem. Eng. Technol. 2012, 35, 238-246.

[23] Brillas, E.; Sirés, I.; Oturan, M. A., Electro-Fenton process and related electrochemical technologies based on Fenton's reaction chemistry. Chem. Rev. 2009, 109, 6570-6631.

[24] Sirés, I.; Brillas, E., Remediation of water pollution caused by pharmaceutical residues based on electrochemical separation and degradation technologies. A review. Environ. Int. 2012, 102, 212-229.

[25] Dirany, A.; Sirés, I.; Oturan, N.; Özcan, A.; Oturan, M. A., Electrochemical treatment of the antibiotic sulfachloropyridazine: kinetics, reaction pathways and toxicity evolution. Environ. Sci. Technol. 2012, 46, 40744082 .

[26] Dirany, A.; Sirés, I.; Oturan, N.; Oturan, M. A., Electrochemical abatement of the sulfamethoxazole from water. Chemosphere 2010, 81, 594-602.

[27] Mansour, D.; Fourcade, F.; Bellakhal, N.; Dachraoui, M.; Hauchard, D.; Amrane, A., Biodegradability improvement of sulfamethazine solutions by means of electro-Fenton Process. Water Air Soil Pollut. 2012, 223 , 2023-2034.

[28] Sirés, I.; Oturan, N.; Oturan, M. A.; Rodríguez, R. M.; Garrido, J. A.; Brillas, E., Electro-Fenton degradation of antimicrobials triclosan and triclocarban. Electrochim. Acta 2007, 52, 5493-5503.

[29] Ferrag-Siagh, F.; Fourcade, F.; Soutrel, I.; Aït-Amar, H.; Djelal, H.; Amrane, A., Tetracycline degradation and mineralization by the coupling of an electro-Fenton pretreatment and a biological process. J. Chem. Technol. Biotechnol. 2013, 88, 1380-1386.

[30] El-Ghenymy, A.; Rodríguez, R. M.; Arias, C.; Centellas, F.; Garrido, J. A.; Cabot, P. L.; Brillas, E., ElectroFenton and photoelectro-Fenton degradation of the antimicrobial sulfamethazine using a boron-doped diamond anode and an air-diffusion cathode. J. Electroanal. Chem. 2013, 701, 7-13.

[31] Cheng, W.; Yang, M.; Xie, Y.; Liang, B.; Fang, Z.; Tsang, E. P., Enhancement of mineralization of metronidazole by the electro-Fenton process with a $\mathrm{Ce} / \mathrm{SnO}_{2}-\mathrm{Sb}$ coated titanium anode. Chem. Eng. J. 2013, 220, 214-220.

[32] El-Ghenymy, A.; Cabot, P. L.; Centellas, F.; Garrido, J. A.; Rodríguez, R. M.; Arias, C.; Brillas, E., Mineralization of sulfanilamide by electro-Fenton and solar photoelectro-Fenton in a pre-pilot plant with Pt/airdiffusion cell. Chemosphere 2013, 91, 1324-1331.

[33] Ledezma Estrada, A.; Li, Y. Y.; Wang, A., Biodegradability enhancement of wastewater containing cefalexin by means of the electro-Fenton oxidation process. J. Hazard. Mater. 2012, 227-228, 41-48.

[34] Lin, S. H.; XChang, C. C., Treatment of landfill leachate by combined electro-Fenton oxidation and sequencing batch reactor method. Wat. Res. 2000, 34, 4243-4249.

[35] Khoufi, S.; Aloui, F.; Sayadi, S., Treatment of olive oil mill wastewater by combined process electro-Fenton reaction and anaerobic digestion. Wat. Res. 2006, 40, 2007-2016. 
[36] Moussavi, G.; Bagheri, A.; Khavanin, A., The investigation of degradation and mineralization of high concentrations of formaldehyde in an electro-Fenton process combined with the biodegradation. J. Hazard. Mater. 2012, 237-238, 147-152.

[37] Brillas, E.; Baños, M. A.; Skoumal, M.; Cabot, P. L.; Garrido, J. A.; Rodríguez, R. M., Degradation of herbicide 2,4-DP by anodic oxidation, electro-Fenton and photoelectro-Fenton using platinum and boron-doped diamond anodes. Chemosphere 2007, 68, 199-209.

[38] Bandara, J.; Pulgarin, C.; Péringer, P.; Kiwi, J., Chemical (photo-activated) coupled biological homogeneous degradation of p-nitro-o-toluene sulfonic acid in a flow reactor. J. Photochem. Photobiol. A 1997, $111,253-263$

[39] Parra, S.; Sarria, V.; Malato, S.; Péringer, P.; Pulgarin, C., Photochemical versus coupled photochemicalbiological flow system for the treatment of two biorecalcitrant herbicides: metobromuron and isoproturon. Appl. Catal., B 2000, 27, 153-168. 
Table 1. TOC, COD, AOS, COD/TOC, BOD 5 and biodegradability determination of tylosin and treated tylosin.

\begin{tabular}{|c|c|c|c|c|c|c|}
\hline Treatment time (h) & TOC $\left(\mathrm{mg} \mathrm{L}^{-1}\right)$ & $\mathrm{COD}\left(\mathrm{mgO}_{2} \mathrm{~L}^{-1}\right)$ & AOS & $\mathrm{COD} / \mathrm{TOC}$ & $\mathrm{BOD}_{5}\left(\mathrm{mgO}_{2} \mathrm{~L}^{-1}\right)$ & $\mathrm{BOD}_{5} / \mathrm{COD}$ \\
\hline 0 & 58.60 & 136 & 0.52 & 2.32 & 0 & 0 \\
\hline 2 & 32.24 & 46 & 1.87 & 1.42 & 14 & 0.3 \\
\hline 4 & 22.00 & 30 & 1.95 & 1.36 & 15 & 0.5 \\
\hline 6 & 6.80 & 5 & 2.90 & 0.73 & 3 & 0.6 \\
\hline
\end{tabular}




\section{Figure legends}

Figure 1.Chemical structure of tylosin tartrate.

Figure 2. Degradation time-course of $100 \mathrm{mg} \mathrm{L}^{-1} \mathrm{TYL}$ during electro-Fenton treatment; experimental conditions: $\left[\mathrm{Fe}^{2+}\right]=0.1 \mathrm{mM} ; \mathrm{I}=300 \mathrm{~mA} ;\left[\mathrm{Na}_{2} \mathrm{SO}_{4}\right]=510^{-2} \mathrm{M} ; \mathrm{pH}=3 ; \mathrm{V}=600 \mathrm{~mL}$.

Figure 3. Time-courses of tylosin mineralization during electro-Fenton pre-treatment (initial concentration $=100$ $\mathrm{mg} \mathrm{L}^{-1}$ ) for $300 \mathrm{~mA}$ current intensity, at $\mathrm{pH} 3, \mathrm{~V}=600 \mathrm{~mL},\left[\mathrm{Na}_{2} \mathrm{SO}_{4}\right]=510^{-2} \mathrm{M}$ and $\left[\mathrm{Fe}^{2+}\right]=0.1 \mathrm{mM}$.

Figure 4. Time-courses of biosorption on activated sludge at $25^{\circ} \mathrm{C}$ and initial $\mathrm{pH} 7$ of tylosin solutions $(100 \mathrm{mg}$ $\mathrm{L}^{-1}$ initial concentration) electrolyzed during $2 \mathrm{~h}(\mathrm{\circ})$ and $4 \mathrm{~h}(\Delta)$ at $\mathrm{pH} 3, \mathrm{I}=300 \mathrm{~mA}, \mathrm{~V}=600 \mathrm{~mL},\left[\mathrm{Na}_{2} \mathrm{SO}_{4}\right]=5$ $10^{-2} \mathrm{M}$ and $\left[\mathrm{Fe}^{2+}\right]=0.1 \mathrm{mM}$.

Figure 5. Time-courses of $\left(\mathrm{TOC}_{\mathrm{t}} / \mathrm{TOC}_{0}\right)$ values during activated sludge culture at $25^{\circ} \mathrm{C}$ and an initial $\mathrm{pH} 7$ of $100 \mathrm{mg} \mathrm{L}^{-1}$ tylosin $(\square)$ and tylosin solutions electrolyzed during $2 \mathrm{~h}(\circ)$ and $4 \mathrm{~h}(\Delta)$ at $\mathrm{pH} 3, \mathrm{I}=300 \mathrm{~mA}, \mathrm{~V}=600$ $\mathrm{mL},\left[\mathrm{Na}_{2} \mathrm{SO}_{4}\right]=510^{-2} \mathrm{M}$ and $\left[\mathrm{Fe}^{2+}\right]=0.1 \mathrm{mM}$. 
Figure 1

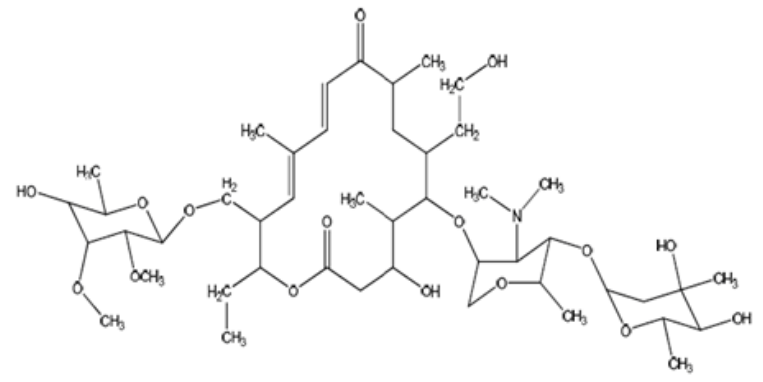


Figure 2

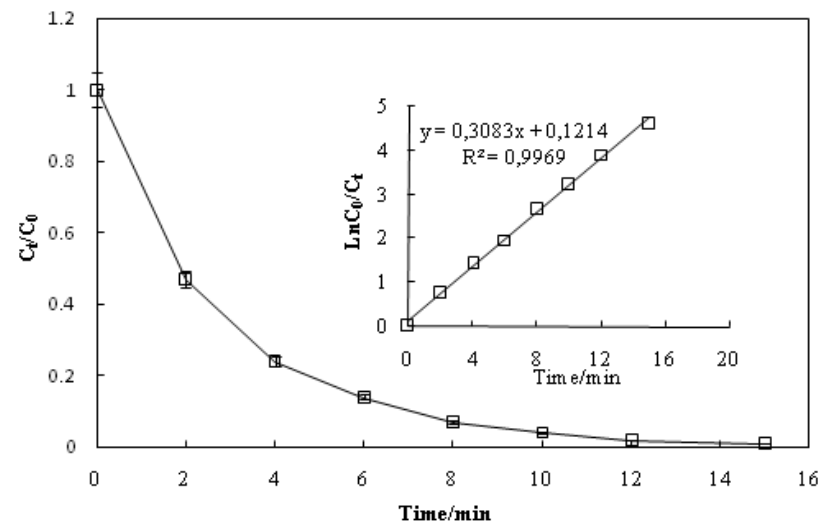


Figure 3

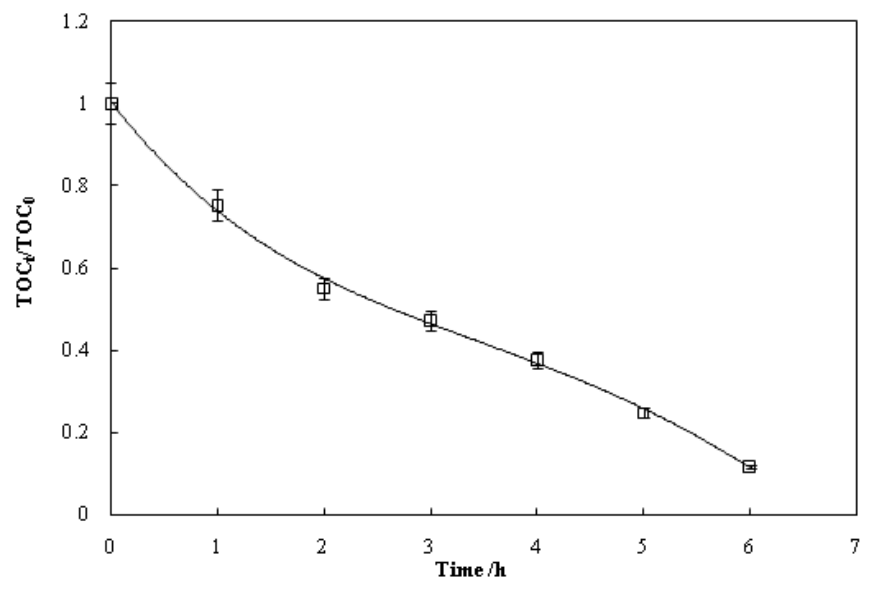


Figure 4

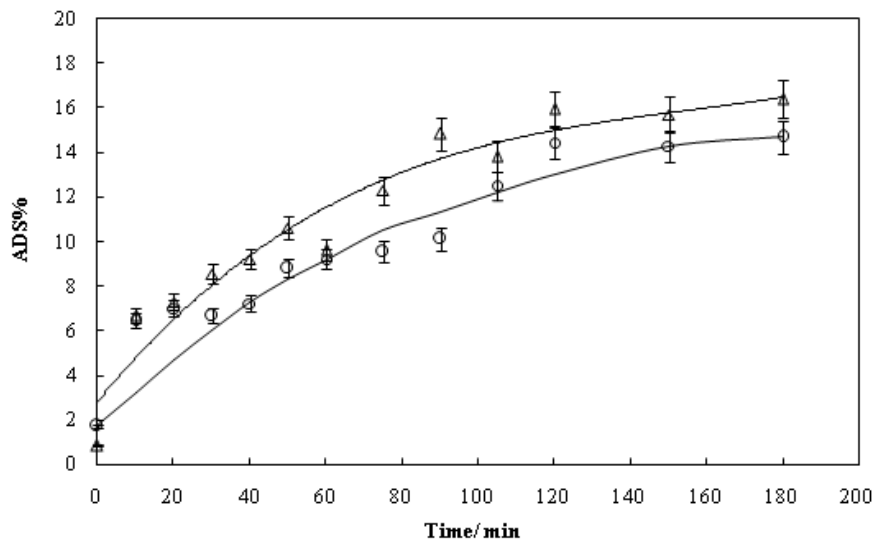


Figure 5

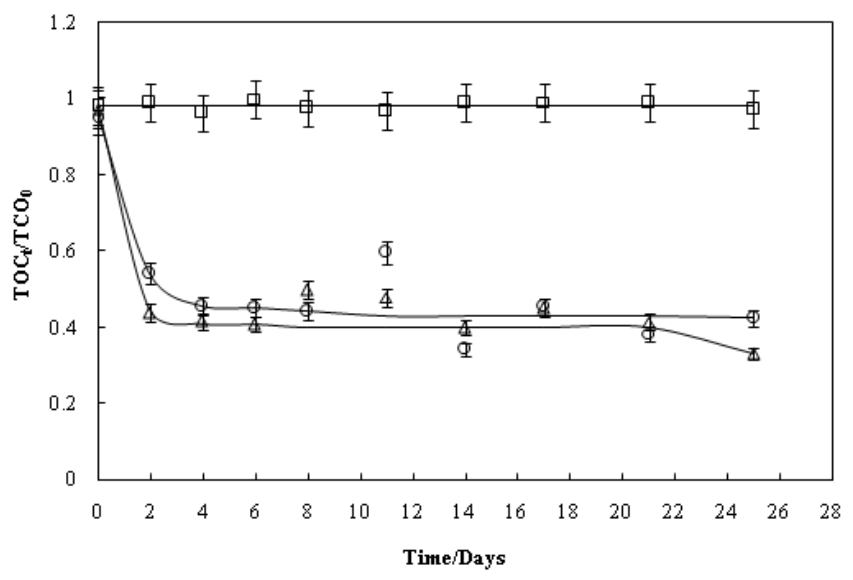

